\title{
Early P1NP Suppression during Treatment of Low Bone Mass Postmenopausal Women with Risedronate 150 mg once-a Month
}

\author{
Gregorio S Riera-Espinoza ${ }^{1,2^{*}}$, Yamila Cordero ${ }^{1}$, Sandra Mendoza ${ }^{1}$, Yuneci González ${ }^{1}$, Jenny Ramos $^{1,2}$ and Jenny \\ C Bello ${ }^{1}$
}

${ }^{1}$ Unidad Metabólica, Centro Policlínico Valencia, South America

${ }^{2}$ Centro de Atención en Menopausia, CEAM, South America

Submission: August 04, 2017; Published: August 17, 2017

*Corresponding author: Riera-Espinoza, Gregorio, Unidad Metabólica, Centro Policlínico Valencia, Valencia, Venezuela and Centro de Atención en Menopausia, CEAM, Venezuela, South America, Tel: +58 +424 4334603; Email: rieragregorio@gmail.com

\begin{abstract}
Objective: The objective of this trial is to evaluate early response of rise dronate $150 \mathrm{mg}$ once-a-month on $\mathrm{N}$-terminal propeptide of procollagen type I (P1NP), a highly specific marker of bone formation in postmenopausal women with low bone mass (T-score below -1.5). Methods. P1NP and serum Beta-Cross Laps (CTx) were evaluated in 80 postmenopausal Venezuelan women with low bone mass (T-score below -1.5) either at lumbar spine or femoral neck (Lunar Prodigy VC 1.5\%). All patients received rise dronate $150 \mathrm{mg} / \mathrm{month}$ and calcium citrate $1500 \mathrm{mg}$ (315mg Calcium ion) plus Vitamin D 200 units/day. P1NP and CTx were measured on fully automated cobas e411 (Electrochemiluminescence immunoassay analyzer).

Results: More than 15\% reduction of initial P1NP values was achieved in 96\% of patients after a year treatment with rise dronate 150/ monthly.P1NP was suppressed $47.5 \%$ at three months $(59.06 \pm 22.3$ vs. $31.01 \pm 17.8 \mathrm{ng} / \mathrm{ml}, \mathrm{p}<0.001)$ and $57.3 \%$ at 12 months $(25.19 \pm 14.32$ $\mathrm{ng} / \mathrm{ml}, \mathrm{p}<0.001$ vs initial). C-telopeptide also showed a $51.1 \%$ reduction at 3 months and $48.8 \%$ at 12 . The results of both bone markers were highly correlated at 12 months of treatment.

Conclusions: This study support the use of changes in P1NP as good indicator of treatment effectiveness with risedronate $150 \mathrm{mg}$ monthly, early at three months or sustained at 12 months in postmenopausal women with low bone mass. P1NP was suppressed into normal premenopausal range in $96 \%$ of patients at 12 months of treatment.
\end{abstract}

Keywords: P1NP; Risedronate 150; CTx; Bone marker; Low one mass; Bone formation marker.

\section{Introduction}

Postmenopausal osteoporosis, known as a "silent disease" is a debilitating disorder associated with increased morbidity and mortality. It is characterized by loss of bone mass and micro architecture deterioration, resulting in an increased risk of fracture. As a chronic disease, treatment compliance is low and in many instances the primary goal of treatment is not achieved. Bisphosphonates are recognized as effective for the treatment and prevention of osteoporosis fractures. Risedronate is a pyridinyl bisphosphonate; It has been shown to reduce vertebral and nonvertebral fracture risks [1-3] in prospective trials with a $5 \mathrm{mg}$ daily dose. Also risedronate $35 \mathrm{mg}$ once a week and 75 mg each day for two consecutive days a month showed similar efficacy and safety than the oral $5 \mathrm{mg}$ dose [4,5]. Later $150 \mathrm{mg}$ monthly dose was compared with daily dosing showing same efficacy and tolerability and was non-inferior to the 5 mg-dose [6].

Once-monthly risedronate dose has proved to be as effective as once-daily in osteoporosis treatment $[7,8]$, and has the possibility of compliance improvement. Bone markers are surrogates of bisphosphonate efficacy, especially highly specific resorption bone markers as $\mathrm{C}$ or $\mathrm{N}$ telopeptides and formation markers, N-terminal propeptide of procollagen type I (P1NP) or bone specific alkaline phosphatase. IOF and the FDC have suggested the use of $\mathrm{C}$ telopeptide and P1NP as gold standards in clinical osteoporosis research due to low variability, good specificity and availability in automatized procedures [9]. The goal of this trial is to evaluate response of risedronate 150 mg once-a-month on P1NP, a highly specific marker of bone 
formation and its correlation with another high specific marker of bone resorption, $\mathrm{C}$ telopeptide after 1 year treatment in women with low bone mass. To our knowledge this has not been published with this specific dose of risedronate.

\section{Materials and Methods}

Population: 80 postmenopausal Venezuelan women with low bone mass (T-score below -1.5) either at lumbar spine (LS) or femoral neck (FN) were included in the study. Patients were excluded if they had secondary osteoporosis, a fracture in the previous 6 months or had received corticosteroids, other bisphosphonates, raloxifen, calcitriol, thyroid hormones, estrogens, anticonvulsant drugs, insulin or diuretics. Also were excluded patients with renal insufficiency, kidney stones secondary to hypercalciuria, hepatic insufficiency, allergy to risedronate or if they had plans of major diet or physical activity changes for the following year.

\section{Treatment Intervention}

Patients received risedronate $150 \mathrm{mg} /$ monthly for 12 consecutive months. They also received calcium citrate 1500 $\mathrm{mg}$ /day mg (315mg Calcium ion) and 200 IU of Vitamin D3. All products from Laboratorios Leti, Venezuela

Table 1: BMD and laboratory values: initial, at 3 and 6 months of treatment with monthly $150 \mathrm{mg}$ risedronate.

\begin{tabular}{|c|c|c|c|c|}
\hline & Initial & 3 months & 12 months & $P(<0.05)$ \\
\hline BMD LS gr $/ \mathrm{cm}^{2}$ & $0.889 \pm 0.1$ & & $0.918 \pm 0.1$ & $<0.000$ \\
\hline BMD FN gr $/ \mathrm{cm}^{2}$ & $0.768 \pm 0.08$ & & $0.794 \pm 0.08$ & $<0.000$ \\
\hline Ca serum [mg-dl] & $9.66 \pm 0.37$ & $9.72 \pm 0.38$ & $9.66 \pm 0.41$ & ns \\
\hline P serum [mg-dl) & $3.82 \pm 0.46$ & $3.78 \pm 0.41$ & $3.91 \pm 0.43$ & ns \\
\hline Creat serum [mg/dl] & $0.93 \pm 0.1$ & $0.86 \pm 0.1$ & $0.88 \pm 0.14$ & ns \\
\hline P1NP [ng/ml) & $59.06 \pm 22.3$ & $31.01 \pm 17.8$ & $25.19 \pm 14.32$ & $\begin{array}{c}<0.000 \text {, initial vs. } 3 \text { and } 12 \\
\text { mo<0.000 } 3 \text { vs. } 12 \mathrm{mo}\end{array}$ \\
\hline CTx $[\mathrm{ng} / \mathrm{ml}]$ & $0.43 \pm 0.18$ & $0.21 \pm 0.14$ & $0.22 \pm 0.13$ & $\begin{array}{c}<0.000 \text { initial vs. } 3 \text { and } 12 \\
\text { mo ns } 3 \text { vs. } 12 \text { mo }\end{array}$ \\
\hline Urinary $\mathrm{Ca} / \mathrm{creat}$ & $0.19 \pm 0.1$ & $0.17 \pm 0.1$ & $0.15 \pm 0.07$ & ns \\
\hline
\end{tabular}

Bone mineral density of lumbar spine (BMD LS), bone mineral density of femur neck (BMD FN), calcium (Ca), phosphorus (P), creatinine (Creat), N-terminal propeptide of procollagen type I (P1NP), C-telopepide (CTx), urinary calcium/creatinine relation (Urinary Ca/creat). We evaluated the effects of risedronate $150 \mathrm{mg}$ once-a-month on P1NP. It decreased $47.5 \%$ and $57.3 \%$ at 3 and 12 months. P1NP decreased more than $15 \%$ in $96 \%$ of patients at 12 months. P1NP is a good indicator of treatment effectiveness of risedronate $150 \mathrm{mg}$ monthly.
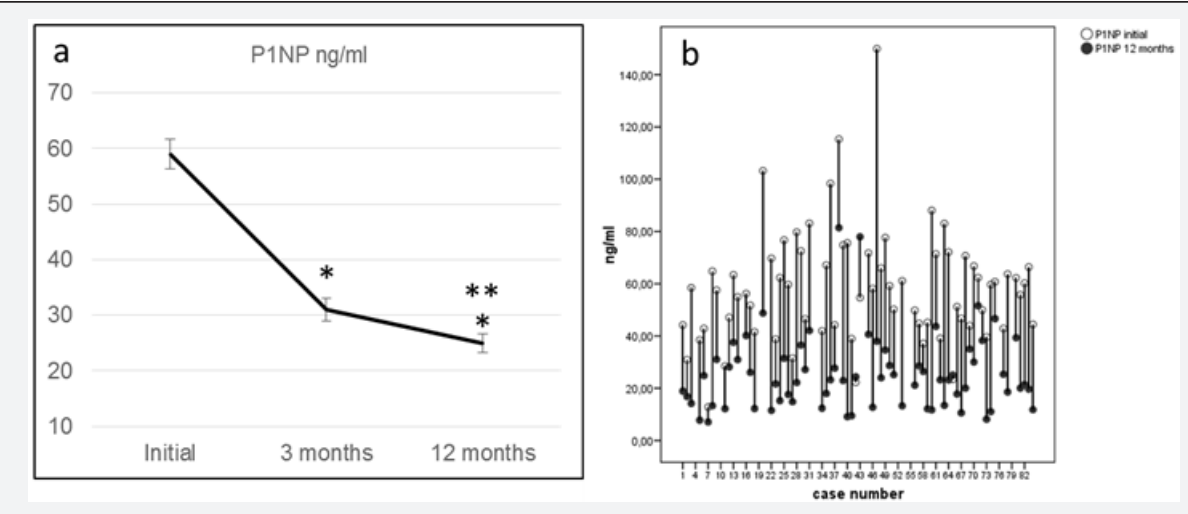

Figure 1: Sustained P1NP suppression with monthly $150 \mathrm{mg}$ risedronate treatment of postmenopausal women with low bone mass during 1 year treatment. a: Total group, initial, 3 and 12 months. b: Individual values initial and 12 months. 
C-telopeptide ( $\beta$ Cross laps), also was suppressed at 3 and 12 months of treatment. Initial $0.43 \pm 0.18 \mathrm{ng} / \mathrm{ml}, 3$ months 0.21 $\pm 0.14 \mathrm{ng} / \mathrm{ml}$ and 12 months $0.22 \pm 0.13 \mathrm{ng} / \mathrm{ml}$. This represents $51.1 \%$ reduction at 3 months and $48.8 \%$ at 12 months, $\mathrm{p}<0.000$ initial vs. 3 and 12 months and no significance between 3 and 12 months. BMD increased $3.58 \%$ at lumbar spine and 3.48\% at femoral neck after 1 year of treatment with risedronate 150 / monthly $\mathrm{p}<0.000$ vs. initial. Serum calcium, phosphorus and creatinine as urinary calcium did not change during the study (Table 1). More than 15\% reduction of initial P1NP values was achieved by $96 \%$ of the patients after a year treatment with risedronate $150 /$ monthly (Figure 1 b). There was a progressive suppression during treatment and $30 \%$ of the patients decreased an extra $10 \%$ of their P1NP values between 3 and 12 months. CTx at 12 months was suppressed more than $15 \%$ of initial values in $66 \%$ of the patients (Table 2). P1NP and CTx were highly correlated at 12 months of treatment with risedronate $150 \mathrm{mg} /$ day, $\mathrm{r} 0.558, \mathrm{p}<0.000$ (Figure 2).

Table 2: Percentage of patients who achieved more than $15 \%$ decrease in P1NP or $\beta$ Cross laps at 3 and 12 months treatment with risedronate $150 \mathrm{mg} / \mathrm{monthly}$.

\begin{tabular}{|c|c|c|}
\hline Bone Marker & At 3 months & At 12 months \\
\hline P1NP & $93 \%$ & $96 \%$ \\
\hline B Cross laps & $85 \%$ & $66 \%$ \\
\hline
\end{tabular}

$\mathrm{N}$-terminal propeptide of procollagen type I (P1NP).

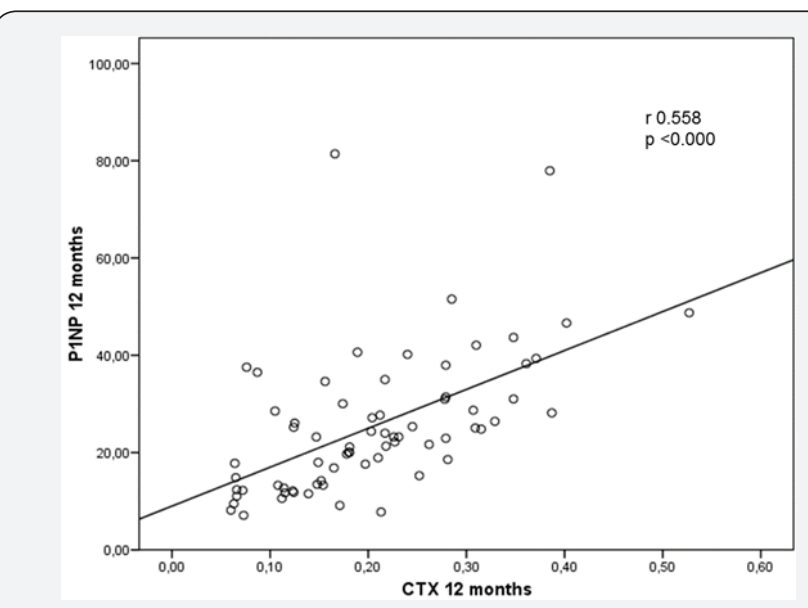

Figure 2: $\mathrm{P} 1 \mathrm{NP}$ and $\mathrm{CTx}$ correlation after 1 year treatment with risedronate $150 \mathrm{mg} / \mathrm{monthly}$.

Adverse events and drop-outs: musculoskeletal and upper GI symptoms occurred in $20 \%$ of the patients, these were mild and stopped after the first 2 or 3 doses however, 9 cases did not completed the trial, 4 due to protocol violation, 1 because diagnosis of pituitary gland tumor and 4 for possible drug related side effects- 2 had upper gastrointestinal tract adverse events (H pylori positive gastritis) and colitis, 2 had significant musculoskeletal and influenza-like post dose symptoms.

\section{Discussion}

This study support changes in P1NP as a good indicator of treatment effectiveness with risedronate $150 \mathrm{mg}$ monthly, early at three months or sustained at 12 months in postmenopausal women with low bone mass. Risedronate once-a-month suppressed bone remodeling into normal premenopausal reference range, with $47.5 \%$ reduction of P1NP at 3 months and $57.3 \%$ at 12 months. To our knowledge changes in P1NP have not been reported with monthly $150 \mathrm{mg}$ dose. Decrease in P1NP has been reported using risedronate $35 \mathrm{mg}$-week dose after 1 year, Bala et al. [10] reported $43 \%$ and $52 \%$ P1NP reduction in women younger than 55 or older respectively. Also in the FACT trial where alendronate was compared to risedronate, P1NP was suppressed by $48 \%$ at 12 months [11]. At 6 months P1NP has been shown to decrease with the use of risedronate $35 \mathrm{mg} /$ week, Anastasilakis et al. [12] reported in a head to head comparison of risedronate vs. teriparatide, $27 \%$ reduction in P1NP after 6 months, but P1NP baseline values were lower than in our study.

The use of bone markers in clinical practice includes fracture risk prediction and treatment follow-up. A recent meta-analysis confirms a modest, but significant association between PINP and CTX concentrations at baseline and fracture risk [13]. Moreover, changes in bone markers haven been associated and explain some of fracture reduction independently of BMD modification during treatment with different anti-resorptives therapies like alendronate [14], risedronate [15], zoledronic acid [16], raloxifene $[17,18]$ or strontium ranelate [19],

Also bone turnover markers might be useful in improving treatment compliance because it demonstrate to the patient the effectiveness of the medication in short period of time [20], especially in osteoporosis where the other surrogate of treatment efficacy, "real improvements" in bone mineral density can be detected probably after 2 year of treatment. In our study the reduction in P1NP was very homogeneous among our cases with $96 \%$ of them achieving more than $15 \%$ reduction in serum values of P1NP at 12 months of treatment, well above the known analytical and intra-individual coefficient of variation [20]. This demonstrates the efficacy of $150 \mathrm{mg}$ once-a-month dose of risedronate in suppressing bone remodeling measured by highly specific bone formation marker as it is P1NP. CTx values also showed significant changes with $66 \%$ of patients achieving a $15 \%$ reduction at 12 months. Both markers P1NP and CTx were significantly correlated at 12 months of treatment. BMD, as it is well known, increased at lumbar spine and femoral neck, 3.58\% and $3.48 \%$ respectively.

Although a main limitation of our trial was the low number of cases, we feel that statistical findings let us point out valid conclusions. Furthermore, comparison with other studies which evaluate effect of risedronate $150 /$ monthly on P1NP was not possible due to lacking of data on the subject. In conclusion, this study support the use of changes in P1NP as a good indicator of effectiveness of treatment with risedronate 150 


\section{Orthopedics and Rheumatology Open Access Journal}

mg monthly, early at three months or sustained at 12 months in postmenopausal women with low bone mass. Bone remodeling was suppressed into normal premenopausal reference range, with $47.4 \%$ reduction of P1NP at 3 months and $57.3 \%$ at 12 months. Also $96 \%$ of the patients showed more than $15 \%$ reduction of serum P1NP at 1 year treatment with the use of 150 $\mathrm{mg}$ risedronate once-a-month.

\section{Acknowledgement}

To Laboratorios Leti, Venezuela who provided financial supports for biochemistry measurements and medications for this trial, risedronate 150 and calcium citrate + vitamin D. Also to Lics. Maria A Barreto and Amparo Gonzalez for their technical assistance in lab determinations.

\section{Conflict of Interest}

Riera-Espinoza Gregorio, Cordero Yamila, Mendoza Sandra, González Yuneci, Ramos Jeny, Bello Jenny Carolina declare that they have no conflict of interest.

\section{References}

1. Harris ST, Watts NB, Genant HK, McKeever CD, Hangartner T, Keller $M$, et al. (1999) Effects of risedronate treatment on vertebral and nonvertebral fractures in women with postmenopausal osteoporosis: a randomized controlled trial. Vertebral Efficacy with Risedronate Therapy (VERT) Study Group. JAMA 282(14): 1344-1352.

2. Reginster J, Minne HW, Sorensen OH, Hooper M, Roux C, et al. (2000) Randomized trial of the effects of risedronate on vertebral fractures in women with established postmenopausal osteoporosis. Vertebral Efficacy with Risedronate Therapy (VERT) Study Group. Osteoporos Int 11(1): 83-91.

3. McClung MR, Geusens P, Miller PD, Zippel H, Bensen WG, et al. (2001) Effect of risedronate on the risk of hip fracture in elderly women. $\mathrm{N}$ Engl J Med 344(5): 333-340.

4. Brown JP, Kendler DL, McClung MR, Emkey RD, Adachi JD, et al. (2002) The efficacy and tolerability of risedronate once a week for the treatment of postmenopausal osteoporosis. Calcif Tissue Int 71(2): 103-111.

5. Delmas PD, Benhamou CL, Man Z, Tlustochowicz W, Matzkin E, et al. (2008) Monthly dosing of 75-mg risedronate on 2 consecutive days a month: efficacy and safety results. Osteoporos Int 19(7): 1039-1045.

6. Delmas PD, McClung MR, Zanchetta JR, Racewicz A, Roux C, et al. (2008) Efficacy and safety of risedronate 150-mg once a month in the treatment of postmenopausal osteoporosis. Bone 42(1): 36-42.

7. McClung MR, Zanchetta JR, Racewicz A, Roux C, Benhamou CL, et al. (2013) Efficacy and safety of risedronate 150-mg once a month in the treatment of postmenopausal osteoporosis: 2-year data OateoporosisInt 24: 293-299.

8. Vasikaran S, Cooper C, Eastell R, Griesmacher A, Morris HA, et al. (2011) International Osteoporosis Foundation and International Federation of Clinical Chemistry and Laboratory Medicine Position on bone marker standards in osteoporosis. ClinChem Lab Med 49(8): 1271-1274.
9. Bala Y, Chapurlat R, Cheung AM, Felsenberg D, LaRoche M, et al. (2014) Risedronate Slows or Partly Reverses Cortical and Trabecular Microarchitectural Deterioration in Postmenopausal Women. J Bone Miner Res 29(2): 380-388.

10. Rosen CJ, Hochberg MC, Bonnick SL, McClung M, Miller P, et al. (2005) Treatment with once weekly alendronate $70 \mathrm{mg}$ compared with once-weekly risedronate $35 \mathrm{mg}$ in women with postmenopausal osteoporosis: a randomized double-blind study. J Bone Miner Res 20(1): 141-151.

11. Anastasilakis AD, Goulis DG, Polyzos SA, Gerou S, Koukoulis GN, et al. (2008) Head-to-head comparison of risedronate vs. teriparatide on bone turnover markers in women with postmenopausal osteoporosis: a randomised trial. Int J ClinPract 62(6): 919-924.

12. Johansson H, Odén A, Kanis JA, McCloskey EV, Morris HA, et al. (2014) A meta-analysis of referencemarkers of bone turnover for prediction of fracture. Calcif Tissue Int 94(5): 560-567.

13. Bauer DC, Black DM, Garnero P, Hochberg M, Ott S, et al. (2004) Change in bone turnover and hip, non-spine, and vertebral fracture in alendronate-treated women: the fracture intervention trial. J Bone Miner Res 19(8): 1250-1258.

14. Eastell R, Barton I, Hannon RA, Chines A, Garnero P, (2003) Relationship of early changes in bone resorption to the reduction in fracture risk with risedronate. J Bone Miner Res 18(6): 1051-1056.

15. Delmas PD, Munoz F, Black DM, Cosman F, The HORIZON-PFT Research Group, et al. (2009) Effects of yearly zoledronic acid $5 \mathrm{mg}$ on bone turnover markers and relation of PINP with fracture reduction in postmenopausal women with osteoporosis. J Bone Miner Res 24(9): 1544-1551.

16. Reginster JY, Sarkar S, Zegels B, Henrotin Y, Bruyere O, et al. (2004) Reduction in PINP, a marker of bone metabolism, with raloxifene treatment and its relationship with vertebral fracture risk. Bone 34(2): 344-351.

17. Sarkar S, Reginster JY, Crans GG, Diez-Perez A, Pinette KV, et al. (2004) Relationship between changes in biochemical markers of bone turnover and BMD to predict vertebral fracture risk. J Bone Miner Res 19(3): 394-401.

18. Bruyère 0 , Collette J, Rizzoli R, Decock $C$, Ortolani $S$, et al. (2010) Relationship between 3-month changes in biochemical markers of bone remodelling and changes in bone mineral density and fracture incidence in patients treated with strontium ranelate for 3 years. Osteoporosis Int 21(6): 1031-1036.

19. Delmas PD, Vrijens B, Eastell R, Roux C, Pols HA, et al. (2007) Effect of monitoring bone turnover markers on persistence with risedronate treatment of postmenopausal osteoporosis. J Clin Endocrinol Metab 92(4): 1296-1304.

20. Vasikaran S, Eastell R, Bruyère O, Foldes AJ, Garnero P, et al. (2001) Markers of bone turnover for the prediction of fracture risk and monitoring of osteoporosis treatment: a need for international reference standards. Osteoporos Int 22(2): 391-420. 
This work is licensed under Creative Commons Attribution 4.0 License DOI: $10.19080 /$ OROAJ.2017.08.555732
Your next submission with Juniper Publishers will reach you the below assets

- Quality Editorial service

- Swift Peer Review

- Reprints availability

- E-prints Service

- Manuscript Podcast for convenient understanding

- Global attainment for your research

- Manuscript accessibility in different formats

( Pdf, E-pub, Full Text, Audio)

- Unceasing customer service

Track the below URL for one-step submission https://juniperpublishers.com/online-submission.php 